\title{
Парадигматика и синтагматика видовременных форм русского глагола
}

\section{Paradigmatics and syntagmatics of aspectual-temporal forms of the Russian verb}

\begin{abstract}
This paper addresses the following topics within the framework of natural grammar: On the paradigmatic level of the analysis (The Part titled "Semantics of aspectual-temporal forms of Russian verb"), the temporal and aspectual meanings of each aspectual-temporal form contained in the system of Russian aspectual-temporal forms are determined. On the syntagmatic level of the analysis (The Part titled "Pragmatics of aspectual-temporal forms in Russian"), the use of aspectual-temporal forms in standard and non-standard contexts is investigated as exemplified by performative verbs in the perfective future.
\end{abstract}

Keywords: Russian, natural grammar, markedness, system of aspectual-temporal forms, standard and non-standard contexts

Vladimir Klimonov, Humboldt University of Berlin, Berlin - Germany, klimonow@web.de, ORCID ID: https://orcid.org/0000-0003-1710-2356

\section{Предмет и теоретические основы исследования}

Видовременные формы русского глагола рассматриваются в настоящей работе с позиций теории маркированности в естественной грамматике. В этой теории отношения маркированности между единицами семантического уровня проецируются на отношения маркированности между соответствующими им единицами формального уровня (Wurzel 62-65). Выделяются два уровня анализа видовременных форм: парадигматический и синтагматический. На парадигматическом уровне анализируются отношения маркированности между видовременными формами в системе видовременных форм русского языка (Klimonov 2000: 399-401). На синтагматическом уровне исследуется употребление каждой отдельной видовременной формы в стандартных (немаркированных) и нестандартных (маркированных) контекстах (Klimonov 2000: 383-399). 


\section{Семантика видовременных форм русского глагола}

В русском языке обычно выделяются 5 видовременных форм: настоящее время несовершенного вида (НАCT НCB) пишу, прошедшее время несовершенного вида (ПРОШ НСВ) писал, прошедшее время совершенного вида (ПРОШ СВ) написал, будущее время несовершенного вида (= будущее сложное) (БУД НСВ) буду писать и будущее время совершенного вида (= будущее простое) (БУД СВ) напишу (Švedova 626-628; Klimonov 2002: 68-70).

Вопрос о статусе видовременной формы БУД СВ типа напишу является дискуссионным в лингвистической литературе. Обыкновенно эта форма считается будущим временем СВ или простым будущим - как это принято в академической грамматике русского языка (Švedova 626-628). Александр Исаченко (Isačenko 224-228) рассматривает видовременную форму типа напишу как форму настоящего времени СВ с эксплицитной сигнализацией неактуальности действия. Значение будущего времени у этой формы Исаченко интерпретирует как особый, или частный, случай употребления неактуального настоящего времени. Александр Бондарко (Bondarko 50-56, 102-112) рассматривает форму типа напишу как многозначную, т. е. семантически двойственную форму, объединяющую значения будущего и настоящего времени, и предлагает называть эту форму „настоящим-будущим совершенным". Авторы академической грамматики русского языка, изданной в Праге (Horálek 167, 237), расчленяют эту форму в структурном отношении на две омонимические (синкретические) формы: немаркированную по временному признаку форму настоящего времени СВ напищу и м маркированную по признаку времени форму будущего времени СВ напишу ${ }_{2}$. В настоящей работе форма типа напишу рассматривается на парадигматическом уровне как форма со значением непрошедшего времени CB (HEПРОШ СВ), в которой объединяются формально не дифференцированные значения настоящего и будущего времени (см. таблицу ниже). В формах СВ как маркированного члена видовой оппозиции с признаком целостности глагольного действия ([+ЦЕЛ]) обнаруживаются только два типа временных парадигм, а именно прошедшее время (написал) и непрошедшее время (напишу) в отличие от формы НCB со значением несигнализации целостности действия ([ $\alpha$ ЦЕЛ]), в которой представлены все времена, а именно настоящее время (пишу), прошедшее (писал) и будущее (буду писать). Посредством нейтрализации временных различий в форме непрошедшего времени СВ достигается оптимальное структурирование видовременной системы: вместо возможных 6 видовременных форм (как продукта пересечения трех временных парадигм с двучленной парадигмой вида) в рус- 
ском языке выступают только 5 видовременных форм. В соответствии с принятым здесь критерием употребления формы непрошедшего времени $\mathrm{CB}$ в ней на синтагматическом уровне разграничиваются немаркированное значение будущего времени, выступающее в стандартных контекстах, и маркированное значение настоящего времени, обнаруживающееся в нестандартных контекстах.

Таблица. Система видовременных форм глагола в современном русском языке

\begin{tabular}{|c|c|c|c|}
\hline \multirow[b]{2}{*}{ Виды } & \multirow[t]{2}{*}{ Прошедшее время } & \multicolumn{2}{|c|}{ Непрошедшие времена } \\
\hline & & Будущее время & Небудущее время \\
\hline $\begin{array}{l}\text { Несовершенный } \\
\text { вид }\end{array}$ & $\begin{array}{l}\text { Прошедшее } \\
\text { время } \\
\text { несовершенного } \\
\text { вида } \\
\text { писал }\end{array}$ & $\begin{array}{l}\text { Будущее время } \\
\text { несовершенного } \\
\text { вида } \\
\text { буду } \\
\text { nuсать }\end{array}$ & $\begin{array}{l}\text { Настоящее } \\
\text { время } \\
\text { несовершенного } \\
\text { вида } \\
\text { пишу }\end{array}$ \\
\hline $\begin{array}{l}\text { Совершенный } \\
\text { вид }\end{array}$ & $\begin{array}{l}\text { Прошедшее } \\
\text { время } \\
\text { совершенного } \\
\text { вида } \\
\text { написал }\end{array}$ & \multicolumn{2}{|c|}{$\begin{array}{l}\text { Непрошедшее время } \\
\text { совершенного } \\
\text { вида } \\
\text { напиму }\end{array}$} \\
\hline
\end{tabular}

На парадигматическом уровне анализируются темпоральные и аспектуальные параметры системы видовременных форм. Во временном плане формы ПРОШ НСВ типа писал и ПРОШ СВ типа написал, маркированные семантически посредством признака предшествия действия моменту речи ([+ПРЕД]) и формально посредством суффикса -л-, противопоставляются всем другим видовременным формам, не сигнализирующим отнесенности действия к прошлому ([ $\alpha$ ПРЕД]) и не обнаруживающим претеритального суффикса -л-. В зоне непрошедших времен маркированные по признаку следования действия после момента речи ([+СЛЕД]) видовые формы БУД НСВ типа буду писать и БУД СВ типа напишу, противопоставляются немаркированной по этому признаку ([ $\alpha$ СЛЕД]) форме НАСТ НСВ типа nuшу. Видовые противопоставления структурируются в соответствии со значением признака разобщенности действия с моментом речи ([РАЗ]). Маркированные по этому признаку формы ПРОШ НСВ типа писал и БУД НСВ типа буду писать с положительным значением признака разобщенности действия с моментом речи ([+РА3]) противопоставляются немарки-

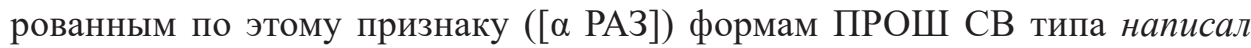
и БУД СВ типа напищу. 


\section{Прагматика видовременных форм глагола в русском языке}

В этом разделе на примере формы БУД СВ рассматривается функционирование перформативных глаголов (или перформативов) на синтагматическом уровне. К перформативам относятся глаголы речи типа попрошy, произнесение которых оказывается сопряженным с речевым актом, т. е. с реальным действием говорящего. Это отличает их от констативов, т. е. языковых выражений, называющих положение дел. Перформативы автореферентны: они называют действия и являются одновременно самими действиями. Перформативы обозначают осуществление (или реализацию) действия, являющегося содержанием перформативного глагола в момент речи. В славистике перформативы типа попрошу в русском и в других северославянских языках рассматриваются как настоящее время СВ (перфективный презенс), тогда как в южнославянских языках их эквиваленты выражаются формой будущего времени СВ (перфективным футурумом) (Vojvodič 27-30).

В примере (1) говорящий высказывает свою просьбу адресату, что является одновременно и самим актом просьбы. Акт просьбы в этом случае выполняется посредством произнесения слова попрошу. Момент произнесения просьбы является в то же самое время и моментом осуществления просьбы как действия.

(1) Попрошу Вас помочь мне решить эту задачу.

У перформативных глаголов типа попрошу наряду с основным перформативным значением встречается и периферийное неперформативное значение будущего времени, которое обнаруживается в футуральном контексте, см. пример (2):

(2) Если я не решу эту задачу, то попрошу Вас помочь мне.

Перформативное значение могут иметь в специальных контекстах и глаголы, у которых основным значением является неперформативное значение. Главное неперформативное значение глагола закончу манифестируется как будущее время СВ (см. пример [3]):

(3) Весной следующего года я закончу обучение в университете.

Если же в высказывании содержится эксплицитное указание актуальности действия, то рассматриваемые глаголы в таком контексте приобретают значение перформативного действия. Так, в примере (4) говорящий назы- 
вает действие, которое является одновременно актом завершения доклада в момент речи, эксплицитно указанный в контексте высказывания:

(4) На этом я и закончу/заканчиваю свой доклад.

В этом примере контекстуальный маркер актуального настоящего времени на этом со значением hic et nunc (,здесь и теперь”) и глагольная форма закончу со значением будущего времени (ср. пример [3]) находятся в противоречии друг с другом. Это противоречие снимается тем, что глагол закончу получает в высказывании (4) значение перфективного презенса. Форма имперфективного презенса заканчиваю с процессуальным значением совместима со значением актуального настоящего времени, выражаемого посредством контекстуального маркера на этом.

В традиионном понимании интерпретация форм типа попрошу, закончу с перформативным значением как форм перфективного презенса исключается по причине несовместимости значения СВ со значением актуального (или конкретного) настоящего времени (Bondarko 50-56). В шестичленной модели категоризации русских видовременных форм, представленной в пражской академической грамматике русского языка, предусмотрена специальная форма перфективного презенса, в которой анализируются случаи употребления настоящего времени СВ в значении неактуального настоящего времени (Horálek 173-175). Перформативы типа попрошу, скажу рассматриваются в этой модели как формы со значением непосредсвенно предстоящего будущего действия. При этом разграничиваются две временные фазы действия: наступление (или начало) действия, совпадающее с моментом речи, и результат действия, относящийся к временному плану, следующему после момента речи. Формы будущего времени СВ обозначают в таких случаях действия, подлежащие реализации непосредственно после момента речи (Horálek 183).

В настоящей работе представлена иная точка зрения, расходящаяся с традиционной трактовкой перформативов как форм будущего времени. Понимание перформативных глаголов как форм будущего времени находится в противоречии со значением актуального настоящего времени, которое обнаруживается как у собственно перформативных глаголов типа попрошу, так и у неперформативных глаголов в перформативном употреблении типа закончу. У собственно перформативных глаголов значение актуальности действия имплицируется самой семантикой глагола, у неперформативных глаголов в перформативном употреблении значение актуального настоящего времени обусловлено контекстом, в котором выступают такие глаголы (см. пример [4]). Пример (5) наглядно показывает, что в таких случаях речь идет 
о презентном, а не о футуральном значении глагола перебью в перформативном употреблении.

(5) Извините, пожалуйста, я Вас перебъю.

В высказывании (5) говорящий выражает свое извинение за то, что он прервал собеседника, не дав ему договорить. Глагол перебью в перформативном употреблении получает здесь значение перфективного презенса. Футуральная интерпретация высказывания (5) тем самым полностью исключается.

В настоящей работе значение СВ считается совместимым со значением актуального настоящего времени. Перформативы в таком понимании выражают значение перфективного презенса. Они обозначают действие, совершившееся в момент речи. В русистике содержатся указания на такой подход к трактовке перформативов. Так, Алексей Караванов (Karavanov 111), опираясь на теорию Эрвина Кошмидера о коинциденции, т. е. совпадении слова и действия, анализирует примеры употребления формы БУД СВ в значении настоящего времени момента речи. Он называет такое употребление императивным настоящим временем. Автор этой статьи (Klimonov 2002: 73-74) приводит примеры, иллюстрирующие значение актуального настоящего времени у неперформативных глаголов в перформативном употреблении типа закончу. Значение актуального настоящего времени у таких глаголов рассматривается им как маркированное временное значение формы БУД $\mathrm{CB}$. Приведенные в этой работе примеры демонстрируют совместимость значения СВ со значением актуального настоящего времени. Особо следует отметить обстоятельное исследование перформативов Юрием Апресяном (Apresân 199-241).

\section{Заключение}

Семантика и прагматика видовременных форм русского глагола исследуется в настоящей работе с позиций концепции маркированности в естественной грамматике. Отношения маркированности анализируются как на парадигматическом уровне, т. е. на уровне структурных отношений отдельных видовременных форм друг к другу, так и на синтагматическом уровне, т. е. на уровне употребления каждой отдельной видовременной формы в стандартных (немаркированных) и нестандартных (маркированных) контекстах.

На парадигматическом уровне проявляется системно организующая роль отношений маркированности. Видовременные формы, связанные меж- 
ду собой отношениями маркированности, образуют в совокупности единую систему взаимосвязанных видовременных форм. Рассмотрение видовременных форм под углом зрения отношений маркированности на парадигматическом уровне позволяет вскрыть механизмы функционирования этих форм и объяснить их организацию как оптимальной системы. На этом уровне исследуются отношения маркированности между видовременными формами во временном плане и в видовом отношении.

На синтагматическом уровне употребления отдельных видовременных форм вводится разграничение между стандартными (немаркированными) контекстами, образующими центр языковой системы, и нестандартными (маркированными) контекстами, составляюшими периферию языка. В настоящей работе рассматривается на примере формы будущего времени совершенного вида (БУД СВ) разряд глаголов с перформативным значением, в который входят как собственно перформативные глаголы типа попрошу, так и неперформативные глаголы типа закончу с контекстуально обусловленным перформативным значением. Перформативные глаголы выступают в форме БУД СВ лишь в особых контекстуальных условиях и потому относятся к периферийному значению этой формы. Реализация глагольного действия у перформативов происходит в момент речи, что является основанием для рассмотрения перформативов как форм со значением актуального настоящего времени СВ. В традиционном понимании значение актуального настоящего времени несовместимо со значением СВ. В работе содержится критика точки зрения, согласно которой перформативы интерпретируются как будущее время непосредственно предстоящего действия. Вызывает возражение и выделение перфективного презенса как особой формы в шестичленной модели категоризации русских видовременных форм в пражской академической грамматике русского языка (Horálek 173-175). Как было показано выше на примере употребления перформативов (см. раздел 3), перфективный презенс употребляется только в специальных маркированных контекстах и потому не может считаться грамматикализованным в той мере, которая свойственна всем другим видовременным формам русского глагола. В этом смысле перфективный презенс является одним из частных значений формы будущего времени СВ.

\section{Библиография}

Apresân, Ûrij. „,Glagoly momental'nogo dejstviâ i performativy v russkom âzyke”. Ûrij D. Apresân. Izbrannye trudy. Integral'noe opisanie âzyka i sistemnẩ leksikografiâ. T. 2. Moskva, Škola „Âzyki russkoj kul'tury”, 1995, s. 199-241.

Bondarko, Aleksandr. Vid i vremâ russkogo glagola. Moskva, Prosveŝenie, 1971. 
Horálek, Karel, red. Russkaâ Grammatika. T. 1. Praha, Academia, 1979.

Isačenko, Aleksandr. „La structure sémantique des temps en russse”. Aleksandr V. Isačenko. Opera selecta: russische Gegenwartssprache, russische Sprachgeschichte, Probleme der slavischen Sprachwissenschaft. München, Fink, 1976, s. 215-229.

Karavanov, Aleksej. „Upotreblenie formy buduŝego vremeni glagolov soveršennogo vida v značenii nastoâŝego vremeni”. Trudy aspektologičeskogo seminara filologičeskogo fakul'teta MGU im. M.V. Lomonosova. T. 1. Moskva, Izdatel'stvo Moskovskogo universiteta, 1997, s. 102-114.

Klimonov, Vladimir. „Paradigmatik und Syntagmatik der aspektuell-temporalen Formen im modernen Russischen”. Zeitschrift für Slawistik, nr 4, 2000, s. 379-403.

Klimonov, Vladimir. „Vzaimodejstvie semantiki vida i semantiki vremeni v sisteme vidovremennyh form russkogo glagola". Osnovnye problemy russkoj aspektologii. Red. E. G. Kolenova. Sankt-Peterburg, Nauka, 2002, s. 68-79.

Švedova, Nataliâ, red. Russkâ̂ grammatika. T. 1. Moskva, Nauka, 1980.

Vojvodič, Dojčil. „Ėffektivnyj prezens ili èffektivnyj futurum? (K voprosu o tipologii slavânskih performativov soveršennogo vida)". Aspektual'naâ semantičeskaâ zona: tipologiâ sistem i scenarij diahroničeskogo razvitiâ. Sbornik statej V Meždunarodnoj Konferencii Komissii po aspektologii Meždunarodnogo Komiteta Slavistov. Red. Mitsusi Kitadzë, Kioto, Tanaka Print, 2015, p. 27-33.

Wurzel, Wolfgang. “On markedness”. Theoretical Linguistics, vol. 24, nr 1, 1998, p. 53-71. 